\title{
Growth and anthraquinone production of Morinda elliptica cell suspension cultures in a stirred-tank bioreactor
}

\begin{abstract}
The effects of medium strategy, number of impellers, aeration mode, and mode of operation on Morinda elliptica cell suspension cultures in a stirred-tank bioreactor are described. A lower number of impellers and continuous aeration contributed toward high cell growth rate, whereas a higher number of impellers reduced cell growth rate, although not anthraquinone yield. The semicontinuous mode could indirectly imitate the larger scale version of production medium strategy and improved anthraquinone production even with $0.012 \%(\mathrm{v} / \mathrm{v})$ antifoam addition. Production medium promoted both growth (maximum dry cell weight of $24.6 \mathrm{~g} / \mathrm{L}$ ) and anthraquinone formation (maximum content of $19.5 \mathrm{mg} / \mathrm{g}$ of dry cell weight), without any necessity for antifoam addition. Cultures in production medium or with higher growth rate and anthraquinone production were less acidic than cultures in growth medium or with lower growth rate and anthraquinone production. Using the best operating variables, growth of M. elliptica cells $(24.6 \mathrm{~g} / \mathrm{L})$ and anthraquinone yield $(0.25 \mathrm{~g} / \mathrm{L})$ were $45 \%$ and $140 \%$, respectively, lower than those using a shake flask culture after 12 days of cultivation.
\end{abstract}

Keyword: Anthraquinone; Bioreactor; Colorant; Medium strategy; Morinda elliptica; Plant cell culture 